\title{
Histopathological Results of the Eyelid Tumors
}

\section{Göz Kapağı Tümörlerinde Histopatolojik Sonuçlarımız}

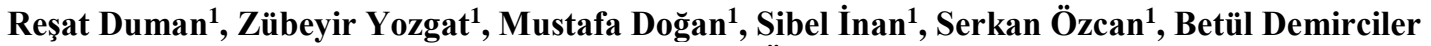 \\ Yavaş², Çiğdem Özdemir ${ }^{2}$ \\ ${ }^{1}$ Afyon Kocatepe Üniversitesi Tıp Fakültesi Göz Hastalıkları Anabilim Dalı \\ ${ }^{2}$ Afyon Kocatepe Üniversitesi Tıp Fakültesi Patoloji Anabilim Dalı
}

Dergiye Ulaşma Tarihi:11.10.2017 Dergiye Kabul Tarihi:29.10.2017 Doi: 10.5505/aot.2018.28290

\begin{abstract}
ÖZET
GİRIŞ ve AMAÇ: Göz Hastalıkları polikliniğine göz kapağında kitle nedeniyle başvuran ve ameliyat edilen olguların retrospektif olarak klinik ve histopatolojik sonuçlarını değerlendirmek amaçlanmıştır.

YÖNTEM ve GEREÇLER: Göz Hastalıkları polikliniğine Mart 2012- Mart 2016 yılları arasında göz kapağında kitle nedeniyle başvuran ve ameliyat edilen 50 olgunun klinik ve histopatolojik sonuçları retrospektif olarak değerlendirildi. Olguların yaşı ve cinsiyeti, kitlenin lokalizasyonu ve histopatolojik tanıları kaydedildi BULGULAR: Çalışmaya dahil edilen 50 olgunun 28' i (\%56) kadın, 22' si (\%44) erkek idi. Olguların yaş ortalaması 54,3 (9- 89) yıl idi. Eksize edilen göz kapağı tümörlerinin histopatolojik sonuçları değerlendirildiğinde; 13 olgu (\%26) malign, 37 olgu (\%74) benign olduğu görüldü. Malign olanlardan 10 olgu (\%76.9) bazal hücreli karsinom (BHK), 2 olgu (\%15.3) skuamoz hücreli karsinom (SHK), bir olgu ise malign epitelyal (\%7.6) tümördü. Benign tümörlerde ise; 13 olgu (\%35.1) skuamoz papillom, 5 olgu (\%13) nevüs, 4 olgu (\%10.8) seboreik keratoz, 3 olgu \%(8.1) verruka vulgaris, 2 olgu (\%5.4) hemanjiom, 2 olgu (\%5.4) epidermal kist, 1 olgu (\%2.7) pilomatrikoma, 1 olgu (\%2.7) ksantolezma, 1 olgu (\%2.7) dermoid kist, 1 olgu (\%2.7) moll gland kist, 1 olgu (\%2.7) epidermal nodul, 1 olgu (\%2.7) fibroepitelyal polip, 1 olgu (\%2.7) sebaseöz adenom, 1 olgu (\%2.7) duktal kist idi.
\end{abstract}

TARTIŞMA ve SONUÇ: Hastanemize başvuran göz kapağı kitllerinin büyük çoğunluğu benign karakterde idi. Malign göz kapağı türmörleri içerisinde bazal hücreli karsinom, benign göz kapağı tümörlerinden ise skuamöz papillom en yaygın alt tanıyı oluşturmaktaydı.

Anahtar Kelimeler: göz kapağı, bazal hücreli karsinom, papillom, nevüs

\begin{abstract}
INTRODUCTION: To evaluate the clinical and histopathologic results of the patients who were admitted to theOphthalmology clinic due to a mass on the eyelids retrospectively.

METHODS: Clinical and histopathologic results of 50 patients who were admitted to ophthalmology polyclinic between March 2012 and March 2016 were evaluated retrospectively. The age and sex of the cases, localization of the mass, and histopathological diagnosis were recorded.

RESULTS: Twenty - eight (56\%) women and 22 (44\%) men were included in the study. The mean age of the cases was 54.3 (9-89) years. When the histopathological results of excised eyelid tumors are evaluated; 13 cases $(26 \%)$ were malignant and 37 cases $(74 \%)$ were benign. Malignant tumors were basal cell carcinoma (BHK) in 10 cases $(76.9 \%)$, squamous cell carcinoma (SHC) in 2 cases $(15.3 \%)$ and malignant epithelial tumor (7.6\%) in one case. Benign tumors were squamous papilloma in 13 cases $(35.1 \%)$, nevus in 5 cases $(10.8 \%)$, seborrheic keratosis in 3 cases $(8.1 \%)$, verruca vulgaris in 2 cases $(5.4 \%$ (2.7\%) epidermal nodule, $1(2.7 \%)$ epidermal nodule, 1 case (2.7\%) xanthole, 1 case $(2.7 \%)$ dermoid cyst, 1 case $(2.7 \%)$ fibroepithelial polyp, 1 case (2.7\%) sebaceous adenoma and 1 case $(2.7 \%)$ ductal cyst.
\end{abstract}

DISCUSSION AND CONCLUSION: The majority of eyelid masses who applied to our hospital were benign. Basal cell carcinoma in malignant eyelid tumors and squamous papilloma in benign eyelid tumors were the most common subtypes.

Keywords: eyelid, basal cell carsinoma, papilloma, nevus 


\section{GíRiș}

Göz kapağ tümörleri oftalmoloji pratiğinde en s1k görülen tümör grubunu oluşturmaktadır. Tüm deri tümörlerinin \%90'1 baş ve buyun çevresinde görülürken; bunlarında yaklaşık $\% 5$ - \%10’u göz kapağı çevresinde yerleşim göstermektedir. ${ }^{1,2}$ Göz kapaklarını oluşturan temel yapılar; cilt ve cilt altı dokular, orbikularis okuli kası, orbital septum, alt ve üst kapak retraktörleri, tars ve konjonktivadır. ${ }^{3} \mathrm{Bu}$ nedenle göz kapağında çok farklı histopatolojik tipte tümör tespit edilebilmektedir.

Göz kapağı tümörleri lezyonun benign ya da malign ayrımı yapıldıktan sonra, alt tiplerine uygun şekilde tedavi edilmelidir. Lokal rekürrens açısından riskli histopatalojik alt tipi olan olgularda adjuvan radyoterapi gerekebilmektedir. Lenf nodu metastazı açısından yüksek risk taşıyan (yassı hücreli karsinoma, melanoma ve sebase bez karsinomu) histopatolojik alt tipi olan olgularda, sentinel lenf nodu biyopsisi uygulanabilmektedir. ${ }^{2}$ Göz kapağı kitlelerinde kesin tan1 ve sonrasinda tedavinin planlanmas1 histopatolojik inceleme ile yapılabilmektedir. ${ }^{4}$

Afyon Kocatepe Üniversitesi Tip Fakültesi Göz Hastalıkları Anabilim Dalı polikliniğine göz kapağında kitle nedeniyle başvuran ve ameliyat edilen olguların retrospektif olarak klinik ve histopatolojik sonuçlarını değerlendirmeyi amaçladık.

\section{MATERYAL VE METOT}

Göz Hastalıkları polikliniğine Mart 2012- Mart 2016 yılları arasında göz kapağında kitle nedeniyle başvuran ve ameliyat edilen 50 olgunun klinik ve histopatolojik sonuçları retrospektif olarak değerlendirildi. Olguların yaşı ve cinsiyeti, kitlenin lokalizasyonu ve histopatolojik tanıları kaydedildi. Tüm olguların patolojik incelemeleri hastanemiz tıbbi patoloji kliniğinde yapıldı. Granülasyon dokusu, yabanc1 cisim ve şalazyon gibi lezyonlar çalışmaya dahil edilmedi.

\section{BULGULAR}

Çalışmaya dahil edilen 50 olgunun 28'i (\%56) kadın, 22' si (\%44) erkek idi. Olguların yaş ortalamas1 54,3 (9-89) y11 idi. Histopatolojik olarak malign lezyon tespit edilen olguların yaş ortalamas1 71,6 y1l iken benign lezyon tespit edilen olguların yaş ortalaması 49,8 y1l idi. $(\mathrm{p}<0,05)$ Malign lezyon tespit edilen olguların 7'si (\%53.8) kadın, 6's1 (\%46.2) erkek iken benign lezyon tespit edilen olgularm 21 'i (\%56.8) kadın, 16's1 (\%43.2) erkekti.

Tüm olguların 26's1 (\%52) üst kapak, 22'si (44) alt kapak, 2'si (\%4) kantus yerleşimliydi. Benign lezyonların 23'ü (\%62.1) üst kapak, 12'si (\%32.4) alt kapak, 2'si (\%5.4) kantus yerleşimliydi. Malign leyonların ise 10'u (\%76.9) alt kapak, 3’ü (\%23) üst kapak yerleşimliydi.

Eksize edilen göz kapağ 1 tümörlerinin histopatolojik sonuçları değerlendirildiğinde; 13 olgu (\%26) malign, 37 olgu (\%74) benign olduğu görüldü. Malign tipte olanlardan 10 olgu (\%76.9) bazal hücreli karsinom (BHK), 2 olgu (\%15.3) skuamoz hücreli karsinom (SHK), bir olgu ise malign epitelyal (\%7.6) tümördü. Bazal hücreli karsinom görülen 10 hasta cinsiyet bakımından 5'i erkek 5'i kadın olmak üzere eşit dağılmıştı 10 olgunun 8 'inde (\%80) lezyon alt kapakta lokalize idi.

Malign olabileceği düşünülen hastalara (18 olguda) preoperatif olarak insizyonel biyopsi planlandi. Bu olgulardan 13 tanesinde malign tipte patolojik rapor gelmesi nedeni ile hastalara total eksizyonel biyopsi uygulandi. $\mathrm{Bu}$ hastalardan hiçbirinde cerrahi sınır pozitif olmadığ sonrası lokal rekurrens izlenmedi.

Benign tipteki tümörlerde ise; 13 olgu (\%35.1) skuamoz papillom, 5 olgu (\%13) nevüs, 4 olgu (\%10.8) seboreik keratoz, 3 olgu $\%(8.1)$ verruka vulgaris, 2 olgu (\%5.4) hemanjiom, 2 olgu (\%5.4) epidermal kist, 1 olgu (\%2.7) pilomatrikoma, 1 olgu (\%2.7) ksantolezma, 1 olgu (\%2.7) dermoid kist, 1 olgu (\%2.7) moll gland kist, 1 olgu (\%2.7) epidermal nodul, 1 olgu (\%2.7) fibroepitelyal polip, 1 olgu (\%2.7) sebaseöz adenom, 1 olgu (\%2.7) duktal kist idi. Benign tümörler içinde en sik görülen tespit edilen skuamoz papillom olgularının 7'si kadın 6's1 erkekti. 13 olgunun 10'nda (\%76.9) üst kapakta lokalizeydi. Tüm olguların yaşı ve cinsiyeti, kitlenin lokalizasyonu ve histopatolojik tanıları tablo 1 de detaylı olarak sunulmuştur.

\section{TARTIŞMA}

Göz kapağ 1 kitlelerinin yıllık insidansı yaklaşık olarak 10000 de 15 olarak bildirilmiştir. ${ }^{2}$ Göz 
kapağ1 kitlelerini diğer tümörlerden ayıran en önemli 2 özelliği; farklı birçok dokudan köken alması ve göz kapağının hem kozmetik hemde fonksiyonel olarak önemli bir role sahip olması ifade edilebilir. ${ }^{2}$ Göz kapağı kitlelerinde kitlenin histopatolojik incelemesi tan1 ve tedavinin en önemli basamağını oluşturmaktadır.

Çalışmamızda göz kapağında kitle nedeniyle ameliyat edilen olguların yaş ortalamas1 54.32 y1l idi. Benzer şekilde ülkemizden yapılan 107 hastanın dahil edildiği bir çalışmada yaş ortalaması 49,44 y1l bulunurken, diğer 74 hastanın dahil edildiği başkabir çalışmada ise yaş ortalaması 47.7 y1 olarak tespit edilmiştir. 5,6 Malign lezyonlu olguların yaş ortalaması $71.6 \mathrm{y} 1$, benign lezyonlu olguların yaş ortalaması 49.8 yıl tespit edilirken malign lezyonlu olguların yaş ortalaması belirgin olarak yüksek bulundu $(\mathrm{p}<0,05) \mathrm{Bu}$ veriye dayanarak, yaşlı hastalarda saptanan kitlelerin gençlerde saptananlara oranla malign olma ihtimalinin daha yüksek olduğu ve yaşlı hastalardaki kitlelere daha fazla kuşku ile yaklaşılması gerektiği düşünülebilir. Bununla beraber serimizde bazal hücreli karsinom tanısı alan 2 hastanın yaşlarının 44 ve 48 olması, kapak kitleleri tanısında her zaman histopatolojik tanının konulması gerektiğini de göstermektedir. Kurt A ve ark çalışmasında benzer şeklide histopatolojik olarak iyi huylu göz kapağı tümörü çıkan grupta yaş ortalaması

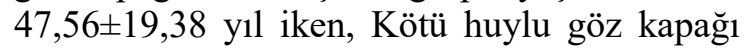
tümörü çıkan grupta yaş ortalamas1 $70,00 \pm 11,13$ y1l bulunmuştur. ${ }^{5}$

Çalışmamız cinsiyet dağılımı açısından incelendiğinde ise; 50 olgunun 28' i (\%56) kadın, 22' si (\%44) erkek idi. Kurt ve ark çalışmasında ise 107 hastanın 61'i erkek, 46's1 kadın olduğu tespit edilirken, Erdoğan ve ark çalışmasında ise 38 'i erkek, 36'sı kadın idi. ${ }^{5,6}$

Tüm olguların 26's1 (\%52) üst kapak, 22'si (44) alt kapak, 2'si (\%4) kantus yerleşimliydi. Benign lezyonların 23’ü (\%62.1) üst kapak, 12'si (\%32.4) alt kapak, 2'si (\%5.4) kantus yerleşimliydi. Malign leyonların ise 10'u (\%76.9) alt kapak, 3’ü (\%23) üst kapak yerleşimliydi. Olgularımızda literatürle uyumlu olarak malign lezyonlar en sik alt kapak yerleşimli bulunmuştur.

Çalışmamızda göz kapağı tümörlerinin $\% 74$ ünün benign tipte olduğu tespit edilmiştir. Literatürdeki en geniş serilerden bir olan
Deprez ve ark. 5504 olgudan oluşan çalışmasında göz kapağı tümörlerinin \%84'ünü benign lezyonlardan oluştuğunu göstermişlerdir. ${ }^{7} \mathrm{Xu}$ ve ark. çalışmasında 2639 olgunun \%86.2'sini, Pornpanich K ve ark çalışmasında ise tüm olguların \% 71.4' ünü benign lezyonların oluşturduğu tespit edilmiştir. ${ }^{8,9}$ Ülkemizden yapılan Erdoğan $\mathrm{H}$ ve ark çalışmasında ise bizim çalışmamıza benzer şekilde; oran \%68,9 olarak tespit edilmiştir. ${ }^{6}$

Çalışmamızda en sık görülen benign lezyon skuamoz papillom (\%35.1) olarak bulundu. Literatürdeki çalışmalar incelendiğinde; benign lezyonlar içinde skuamoz papillom oranı \%19 - 37 ile değişen oranlarda bildirilmiştir. ${ }^{6,7,10}$ Çalışmamızda en s1k görülen ikinci benign lezyon nevüs (\%13) olarak bulundu. Ülkemizden yapılan 2 ayrı çalışmada da, \%19 oranında benign lezyonlar arasında ikinci sıklıkta nevüs saptanmıştır. ${ }^{6,10}$ Çalışmamızda 4 olguda tespit edilen seboreik keratoz (\%10.8) benign lezyonlar içinde en sik görülen üçüncü lezyon olarak bulundu. Ülkemizde yapılan Kurt ve ark. serisinde seboreik keratoz benign lezyonlar içinde $\% 9.2$ ile üçüncü sıklıkta saptanmıştır. ${ }^{6}$ Uzun A ve ark çalışmasında ise \%14 olguda seboreik keratoz tespit edilirken, Erdoğan ve arkadaşlarının yaptığ çalışmada $\% 7,8$ oranında bildirilmiştir. ${ }_{5,10}$ Deprez ve ark.'nın serisinde \%21 oranında seboreik keratoz tespit edilmiştir. ${ }^{7}$

Bizim çalışmamızda malign tümörler içinde en sık BHK (\%76.9) tespit edilmiştir. Literatürdeki diğer çalışmalar incelendiğinde bizim çalışmamıza benzer şekilde \%65-86 arasında değişen oranlarda BHK tespit edilmiştir. ${ }^{7,11,12}$ Ülkemizde yapılan Kurt A ve ark. yaptığ 107 hastanın dahil edildiğ bir çalışmada BHK 8 olguda $(\% 88,9)$ tespit edilmiştir. ${ }^{6}$ Çalışmamızda ikinci en sık malign tümör SHK (\%15.3) olduğu tespit edilmiştir Lin HY ve ark çalışmasında \%12, Deprez ve ark. çalışmasında \% 7 sıklıkla ikinci en sık görülen malign kapak tümörü SHK tespit edilmiştir. ${ }^{7,11}$ Ülkemizde yapılan çalışmalarda SHK sıklığ \%4.3-19.6 arasında bildirilmiştir. ${ }^{5,13,14,15}$

Sonuç olarak, kliniğimizde yapılan kapak kitle rezeksiyonlarının büyük çoğunluğunu benign lezyonlar oluşturmaktaydı. Benign kapak kitleleri içinde en büyük grubu skuamöz papillom, malign göz kapağ kitlelerinde ise en büyük grubu $\mathrm{BHK}$ oluşturmaktaydı. Benign ve malign göz kapağ 1 kitleleri çok farklı dokulardan köken almaktadır 
ve histopatoloji özellikle malign göz kapağ 1 kitlelerinde erken tan 1 ve tedavinin planlanmasında en önemli basamağ oluşturmaktadır.

\section{Çıkar Çatışması: Yok}

\section{REFERANSLAR}

1. Myers M, Gurwood AS. Periocular malignancies and primary eye care. Optometry, 2001; 72(11): 705-12.

2. Yin VT, Merritt HA, Sniegowski M, Esmaeli B. Eyelid and ocular surface carcinoma: diagnosis and management. Clin Dermatol. 2015 MarApr;33(2):159-69.

3. Duman R, Duman R. Göz Kapağı ve Hastalıkları. Derman Tibbi Yayıncilık Published Online: 19.08.2015

4. Kumar R. Clinicopathologic study of malignant eyelid tumours. 5. Clin Exp Optom 2010; 93:4:2247.

5. Erdoğan H, Demirci Y, Dursun A, ve ark. Göz kapağ1 kit $\neg$ lelerinin histopatolojik sonuçları. Türkiye Klinikleri J Opt $\neg$ halmol. 2013; 22:75-80.

6. Kurt A, Mutlu SN, Yener HI, Bayram N ve ark. Primer göz kapağ1 tümörlerinde histopatoloji sonuçları. Dicle Tıp Derg 2015; 42 (1): 72-77.
7. Deprez M, Uffer S. Clinicopathological features of eyelid skin tumors. A retrospective study of 5504 cases and review of literature, Am J Dermatopathol, 2009, 31(3): 256-62.

8. Xu XL, Li B, Sun XL et al. Eyelid neoplasms in the Beijing Tongren Eye Centre between 1997 and 2006. Ophthalmic Surg Lasers Imaging 2008; 39:367-372.

9. Pornpanich K, Chindasub P. Eyelid tumors in Siriraj Hospital from 2000-2004. J Med Assoc Thai. 2005;88(Supll 9):11-4.

10. Uzun A, Gündüz K, Erden E, Heper OA. İyi huylu göz kapağ1 tümörlerinde klinik ve histopatolojik tan1. Turk J Ophthalmol 2012; 42:43-46

11. Lin HY, Cheng CY, Hsu WM, Kao WH, Chou P. Incidence of eyelid cancers in Taiwan: a 21-year review. Ophthalmology. 2006 Nov;113(11):2101-7.

12. Lee SB, Saw SM, Au Eong KG, Chan TK, Lee HP. Incidence of eyelid cancers in Singapore from 1968 to 1995. Br J Ophthalmol. 1999 May;83(5):595-7.

13. Soysal HG, Markoç F. Invasive squamous cell carcinoma of the eyelids and periorbital region. $\mathrm{Br} \mathrm{J}$ Ophthalmol 2007; 91:325-329.

14. Özkılıç E, Peksayar G. Kapak Tümörlerinin Epidemiyolojik Açıdan Değerlendirilmesi. Turk J Ophthalmol 2003; 33:631-640.

15. Çömez TA, Akçay L, Doğan KÖ. Göz kapaklarının primer kötü huylu tümörleri. Turk J Opthalmol 2012; 42:412-417. 